\title{
Effect of Ethanol Extract of Whole Plant of Trichosanthes cucumerina var. cucumerina L. on Gonadotropins, Ovarian Follicular Kinetics and Estrous Cycle for Screening of Antifertility Activity in Albino Rats
}

\author{
Efectos del Etanol Extraído de la Planta Completa de Trichosanthes cucumerina var. cucumerina \\ L. sobre Gonadotropinas, Cinética Folicular Ovárica y Ciclo para Screening de Actividad \\ Antifertilidad en Ratas Albinas
}

"Devendra N. Kage; ${ }^{* * * * * *}$ Vijaykumar B. Malashetty; *Y. N. Seetharam; *** P. Suresh \& **Saraswati B. Patil.

KAGE, D. N.; MALASHETTY, V. B.; SEETHARAM, Y. N.; SURESH, P. \& PATIL, S. B. Effect of ethanol extract of whole plant of Trichosanthes cucumerina var. Cucumerina L. on gonadotropins, ovarian follicular kinetics and estrous cycle for screening o antifertility activity in albin rats. Int. J. Morphol., 27(1):173-182, 2009.

SUMMARY: Ethanol extract of whole plant of Trichosanthes cucumerina L. var. cucumerina was evaluated for antiovulatory activity in adult rats. The ethanol extract at the doses 200 and $400 \mathrm{mg} / \mathrm{kg}$ body weight (orally) affected the normal estrous cycle showing a significant increase in estrus and metestrus phases and decrease in diestrus and proestrus phases. The extract also significantly reduced the number of healthy follicles (Class I-Class VI) and corpora lutea and increased the number of regressing follicles (Stage IA, Stage IB, Stage IIA, and Stage IIB). The protein and glycogen content in the ovaries were significantly reduced in treated rats. The cholesterol level was significantly increased, whereas, the enzyme activities like 3b-HSD and 17b-HSD were significantly inhibited in the ovary of treated rats. Serum FSH and LH levels were significantly reduced in the treated groups were measured by RIA. In acute toxicity test, neither mortality nor change in the behavior or any other physiological activities in mice were observed in the treated groups. In chronic toxicity studies, no mortality was recorded and there were no significant differences in the body and organ weights were observed between controls and treated rats. Hematological analysis showed no significant differences in any of the parameters examined (RBC, WBC count and Hemoglobin estimation). These observations showed the antiovulatory activity of ethanol extract of whole plant of Trichosanthes cucumerina L. var. cucumerina in female albino rats.

KEY WORDS: Trichosanthes cucumerina L. var. cucumerina; Antifertility; Folliculogenesis; Estrous cycle; Gonadotropins; 3 b-HSD, 17 b-HSD activity; Ovarian steroidogenesis.

\section{INTRODUCTION}

Trichosanthes cucumerina L. var. cucumerina belongs to the family Cucurbitaceae and is distributed throughout India, Bangladesh, Sri Lanka, Burma, Malaysia and Australia (Chakravarty, 1982). It is a perennial climber with an attractive white flower. It is highly bitter in taste, the bitter taste may suppose to contain medicinal properties (Choudhury, 1967) hence being used in various treatments as a cordiotonic, antipyretic, antiperiodic, useful for intestinal worms and leaf juice rubbed over the liver in remittent fever (Kirtikar \& Basu, 2000) skin disease (Chopra et al., 1969) Appetizer, laxative, aphrodisiac and blood purifier
(Shivarajan \& Indira, 1994) root is used to cure bronchitis, headache and boils. Leaves, for biliousness, emetic, externally applied over bald patches of alopecia (Anonymous, 1976) to reduce congestion on congestive cardiac failure (Pullaih, 2006). But no literature was found on the antifertility activity of this plant. After preliminary trials the ethanol extract showed maximum antifertility in rats. Therefore, this study examined the effects of ethanol extract of whole plant of Trichosanthes cucumerina L. var. cucumerina Linn on the estrous cycle, ovarian follicles and serum concentration of gonadotropin hormones.

\footnotetext{
* Biosystematics and Medicinal Plant Laboratory, Department of Botany, Gulbarga University, Gulbarga-585 106, India.

${ }^{* *}$ Reproductive Biology Laboratory, Department of Zoology, Gulbarga University, Gulbarga-585 106, India

${ }^{* * *}$ Department of Molecular Reproduction Development and Genetics, Indian Institute of Science Bangalore- 560 012, India.
} 
KAGE, D. N.; MALASHETTY, V. B.; SEETHARAM, Y. N.; SURESH P. \& PATIL, S. B. Effect of ethanol extract of whole plant of Trichosanthes cucumerina var. Cucumerina L. on gonadotropins, ovarian follicular kinetics and estrous cycle for screening o antifertility activity in albin rats. Int. J. Morphol., 27(1):173-182, 2009.

\section{MATERIAL AND METHOD}

Collection and identification of plant material. The healthy plants of Trichosanthes cucumerina L. var. cucumerina were collected from Kurub Khelagi and Khanapur village of Bhalki Taluk, District Bidar, Karnataka growing along the road side and in the waste land. The identification of plant have been done by using flora of the Presidency of Madras (Gamble, 1935), Flora of Karnataka (Saldhana, 1984) and Flora of Gulbarga District (Seetharam et al., 2000). Specimens of the species have been deposited in the Herbarium of Botany Department, Gulbarga University, Gulbarga (Voucher No. HGUG-804).

Processing and extraction. The whole plant was dried under room temperature without exposure to sun light. The dried plant was powdered and soxhleted with ethanol (95\%) for $24 \mathrm{~h}$. The ethanolic extract was concentrated to dryness in a flash evaporator under reduced pressure and controlled temperature $\left(50-60^{\circ} \mathrm{C}\right)$ to obtain the crude extract. The extract was stored in refrigerator at $4^{\circ} \mathrm{C}$ until used for treatment.

Preliminary screening tests for secondary metabolites and preparation of test solution. The preliminary tests, for the detection of secondary metabolites were carried out in ethanolic extract of Trichosanthes cucumerina L. var. cucumerina by adopting standard methods (Figel, 1960; Gibbs, 1974).

$500 \mathrm{mg}$ of ethanolic extract was dissolved in $100 \mathrm{ml}$ of ethanol and filtered through Whatmann filter paper $\mathrm{N}^{\circ} 1$. Thus, the filtrate obtained was used as test solution for the following preliminary screening tests like alkaloids, flavonoids, glycosides, lignin, phenols, saponins, sterols and tannins.

Animal model. Sexually matured, healthy, colony-bred virgin female rats of Wistar strain, weighing 200-250g were used for the experiments. The rats were housed in polypropylene cages measuring 12 " $\times 10$ " $\mathrm{x} 8$ ", under wellventilated animal house conditions (ambient temperature: $28-31^{\circ} \mathrm{C}$, photoperiod: $12 \mathrm{~h}$ natural light and $12 \mathrm{~h}$ dark; relative humidity: 50-55\%). The rats were given pelleted feed (Hindustan Lever Ltd., India) and tap water ad libitum. The experimental protocol was approved by the Institutional Animal Ethics Committee.

Acute toxicity. The acute toxicity study was performed according to the method Kattan et al., 1994. Adult albino mice (20-25g) of either sex were divided into three groups containing ten animals in each group. Graded doses (200 and $400 \mathrm{mg} / \mathrm{kg}$ b.w.) of ethanol extract of Trichosanthes cucumerina L. var. cucumerina in tween-80 (1\%) were administered orally by means of intragastric catheter to mice. Following administration of the extracts, the animals were observed for toxic symptoms continuously for $2 \mathrm{~h}$ and then frequently for further $4 \mathrm{~h}$, finally overnight. Mortality was recorded. Finally the number of survivors was noted after 24h and these animals were then maintained for further 7 days with observations made daily. Food and water were provided throughout the experiment.

Chronic toxicity test. Albino rats of Wistar strain of either sex, weighing 200-250g were divided into three groups containing six rats each. Group I received $0.2 \mathrm{ml}$ Tween- 80 $(1 \%) / \mathrm{kg} / \mathrm{day}$ and the groups II and III received 200 and $400 \mathrm{mg}$ ethanol extract/kg/day in $0.2 \mathrm{ml}$ tween-80 (1\%) respectively. The treatments were given for 30 days. Toxic manifestations and mortality were recorded daily. Body weights and food intake were measured daily $(500 \mathrm{~g}$ of rat pellets were put on food rack of the cage. Next day the amount of pellets remaining in the rack were taken out and weighed. Since only one rat was housed in one cage. $500 \mathrm{~g}$ of pellets were immediately replaced. The food intake was noted every day at the same time). On $31^{\text {st }}$ day, all the animals were sacrificed by cervical dislocation. The blood was collected for hematological analysis. Hematological parameters measured were RBC, WBC and hemoglobin. The heart, liver, kidney, lung, spleen, adrenals, esophagus, stomach and large intestine were dissected out immediately and separated out from the adherent tissue and weighed to the nearest $\mathrm{mg}$ on an electronic balance. Each weighed organ was standardized for $100 \mathrm{~g}$ body weight of each rat.

Experimentation. The animals were divided into 3 groups consisting of six animals in each group.

- Group I: Control, received 0.2ml Tween-80 (1\%)

- Group II : Received 200mg ethanol extract $/ \mathrm{kg}$ b.w. in $0.2 \mathrm{ml}$ tween-80 (1\%)

- Group III : Received 400mg ethanol extract $/ \mathrm{kg}$ b.w. in $0.2 \mathrm{ml}$ tween-80 (1\%)

All the above treatments were given orally by using intragastric catheter for 30 days to cover six regular estrous cycles. The treatment was started from estrous phase only, as the ovarian activities change markedly from one phase to another phase of estrous cycle. The treatment was given orally everyday between 1000 and $1100 \mathrm{~h}$. The stages of estrous cycle were recorded daily by observing vaginal smears.

Schedule of sacrifices. On $31^{\text {st }}$ day, after $24 \mathrm{hrs}$ of last dosing all the animals were weighed and sacrificed by cervical dislocation. The ovaries were dissected out immediately and separated out from the adherent tissue and weighed to the nearest $\mathrm{mg}$ on an electronic balance. 
KAGE, D. N.; MALASheTTY, V. B.; SEETHARAM, Y. N.; SURESH P. \& PATIL, S. B. Effect of ethanol extract of whole plant of Trichosanthes cucumerina var. Cucumerina L. on gonadotropins, ovarian follicular kinetics and estrous cycle for screening o antifertility activity in albin rats. Int. J. Morphol., 27(1):173-182, 2009.

Histopathological studies. The ovary from one side of each animal was fixed in Bouin's fluid, embedded in paraffin wax, sectioned at $5 \mu \mathrm{m}$, stained with haematoxylin-eosin for follicular studies.

Morphometric analysis. Follicular diameter and morphologies were used to classify follicles by using established methods (Hirshfield, 1991; Sanjay \& Joshi, 1997) as:

- Class I : Small preantral follicles (SPAF) $(<90 \mu \mathrm{m})$.

- Class II: Large preantral follicles (LPAF) (91-260 $\mu \mathrm{m})$.

- Class III : Small antral follicles (SAF) (261-350um).

- Class IV : Medium sized antral follicles (MSAF) (351$430 \mu \mathrm{m})$.

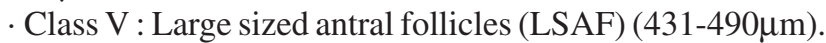

- Class VI: Graafian follicles (GF) (>491 $\mu \mathrm{m})$.

Follicles under regression were classified depending on the degree of regression as:

- Stage IA: Pyknosis in some granulose cells.

- Stage IB: Degenerative changes in the entire granulose layer.

- Stage IIA : Oocytes with pyknotic nuclei, blocked meiosis in metaphase I (pseudo maturation) and degenerating cumulus cells.

- Stage IIB : Characterized by oocytes floating in the antrum with few pyknotic bodies.

Morphometric studies of the ovary were calculated by using stage and ocular micrometers.

Biochemical studies. Ovary from the other side of each animal was used for biochemical estimations like protein (Lowry et al., 1951), glycogen (Carrol et al., 1956), cholesterol (Peters \& Vanslyke, 1946) and enzyme activities of 3b HSD and 17b HSD (Talalay, 1962).

Radioimmunoassay of hormones. Serum FSH and LH levels were assayed by RIA using Coat-A-Count Kit (Los Angeles, US).

Statistical analysis. The data were statistically analyzed and expressed as mean \pm SEM. Statistical analysis of the variance between control and experimental values was done using Student's t Test.

\section{RESULTS}

Acute toxicity. Over the study duration of 7 days, there were no deaths recorded in the animals given 200 and $400 \mathrm{mg} / \mathrm{kg}$ b.w. of ethanol extract of Trichosanthes cucumerina L. var. cucumerina. The animals did not show any change in general behavior, skin effects, defecation, loss of hair or other physiological activities.

\section{Chronic toxicity}

Changes in body weight. Administration of ethanol extract of Trichosanthes cucumerina L. var. cucumerina at 200 and $400 \mathrm{mg} / \mathrm{kg}$ b.w. to female rats has shown no change in the body weight. The treated rats were healthy and maintained normal growth rate throughout the experiment (Fig.1).

Hematological analysis. Blood variables, i.e., RBC, WBC and hemoglobin were within the normal range in 200 and $400 \mathrm{mg} / \mathrm{kg}$ b.w. of ethanol extract of Trichosanthes cucumerina L. var. cucumerina treated rats when compared to control (Fig.2).

Changes in organs weight.There were no significant changes in the weights of the heart, liver, kidney, lung, spleen, adrenals, esophagus, stomach and large intestine treated with 200 and $400 \mathrm{mg} / \mathrm{kg}$ of ethanol extract of Trichosanthes cucumerina L. var. cucumerina (Table II).

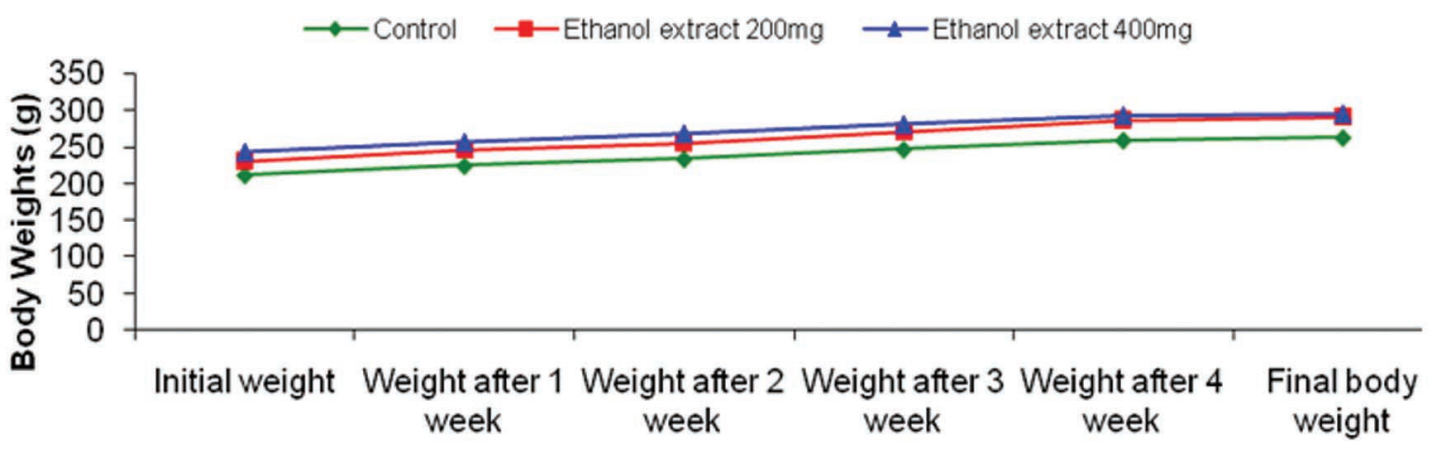

Fig. 1. Changes in the body wight due to administration ethanol extract of Trichosanthes cucumerina L. var. cucumerina for different periods in rats. Data represent the mean \pm SEM. ( $n=6$ for each group). 


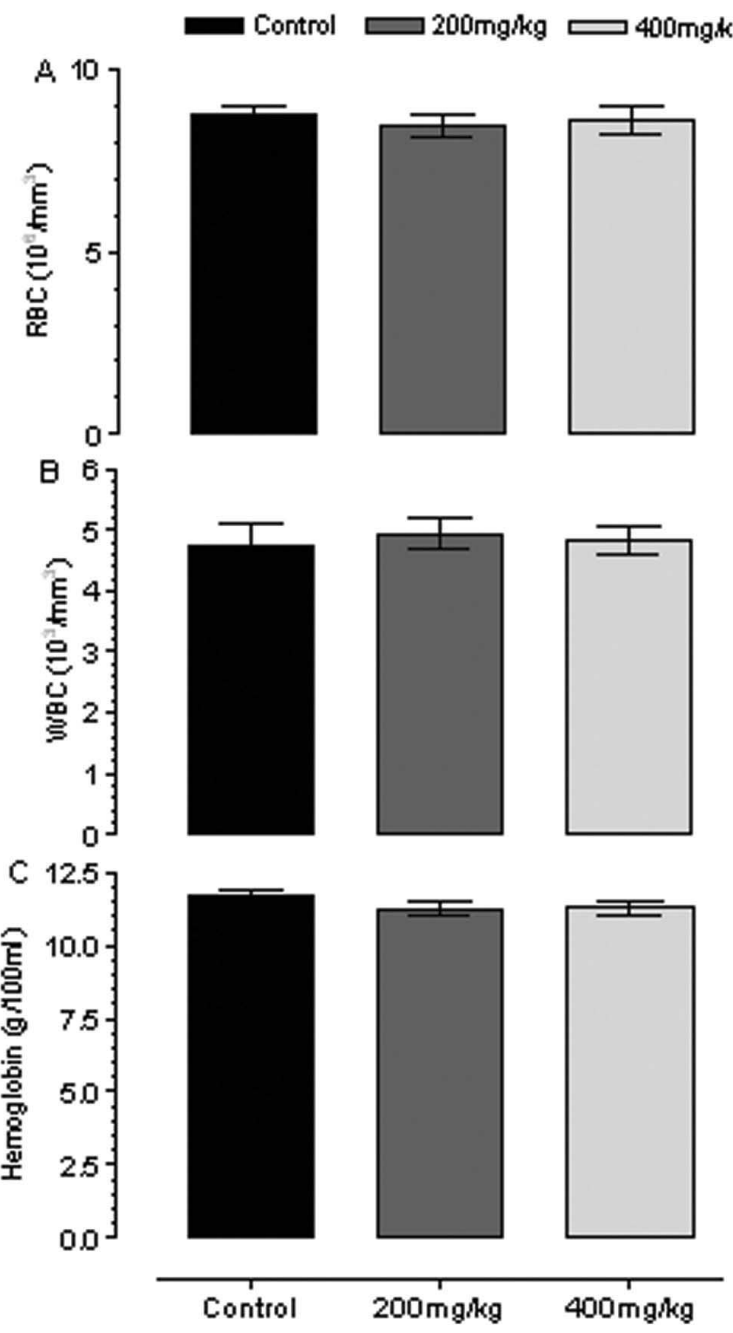

Fig. 2. Effect of ethanol extract of Trichosanthes cucumerina L. var. cucumerina on hematological parameters RBC (A), WBC (B) and hemoglobin $(\mathrm{C})$ in rats.
Estrous cycle. Administration of ethanol extract of Trichosanthes cucumerina L. var. cucumerina at $200 \mathrm{mg} / \mathrm{kg}$ (low dose) increased estrus phase significantly $(\mathrm{P}<0.01)$, whereas $400 \mathrm{mg} / \mathrm{kg}$ (high dose) increased highly significantly $(\mathrm{P}<0.001)$ when compared to control. Both the doses increased the metestrus and decreased the diestrus phases highly significantly $(\mathrm{P}<0.001)$. Both the low and high dose decreased the proestrus phase significantly $(\mathrm{P}<0.01)$ and highly significantly $(\mathrm{P}<0.001)$, respectively (Fig. 3 ).

\section{Changes in the ovary}

Gravimetric changes. Low dose of ethanol extract caused nonsignificant decrease in the ovarian weight, but high dose caused highly significant reduction $(\mathrm{P}<0.001)$ in the ovarian weight when compared to control (Fig.4).

Biochemical changes. Changes after treatment are outlined in Figure 5. There was highly significant decrease $(\mathrm{P}<0.001)$ of protein and glycogen, and increase in the cholesterol content was observed in both the doses when compared to control. The enzyme activities like $3 \mathrm{~b}-\mathrm{HSD}$ and $17 \mathrm{~b}-\mathrm{HSD}$ were decreased nonsignificantly in low dose but significantly $(\mathrm{P}<0.01)$ in high dose treated groups in comparison to the control (Fig. 5).

Changes in follicular kinetics. Healthy follicles: Both the low and high doses decreased the Class I (SPAF) follicles significantly $(\mathrm{P}<0.01)$ and highly significantly $(\mathrm{P}<0.001)$ when compared to control. Class II (LPAF) follicles were decreased significantly $(\mathrm{P}<0.05)$ and highly significantly $(\mathrm{P}<0.001)$ in both low and high doses, respectively. Low and high doses caused nonsignificant decrease and highly significant decrease $(\mathrm{P}<0.001)$ in the number of Class III
Fig. 3. Effect of ethanol extract of Trichosanthes cucumerina L. var. Cucumerina on duration of different phases of estrous cycle. Data represent the mean \pm SEM. ( $\mathrm{n}=6$ for each group). $* \mathrm{P}<0.05, * * \mathrm{P}<0.01, * * * \mathrm{P}<0.001$ statistically significant difference from control.

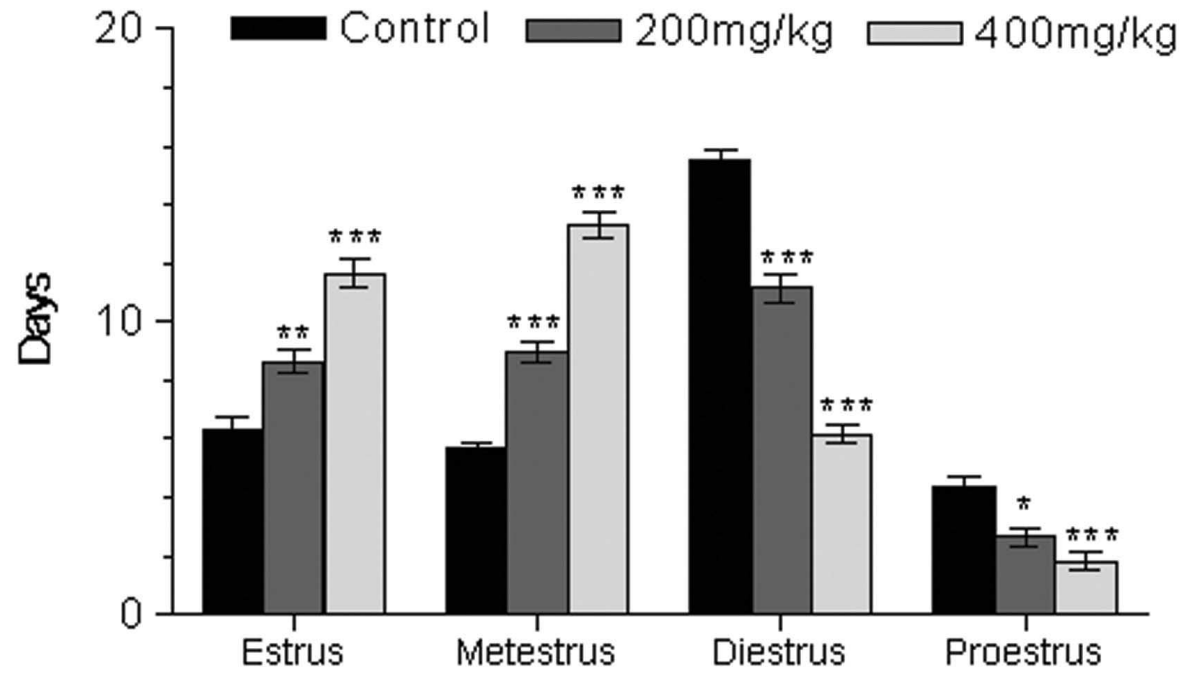




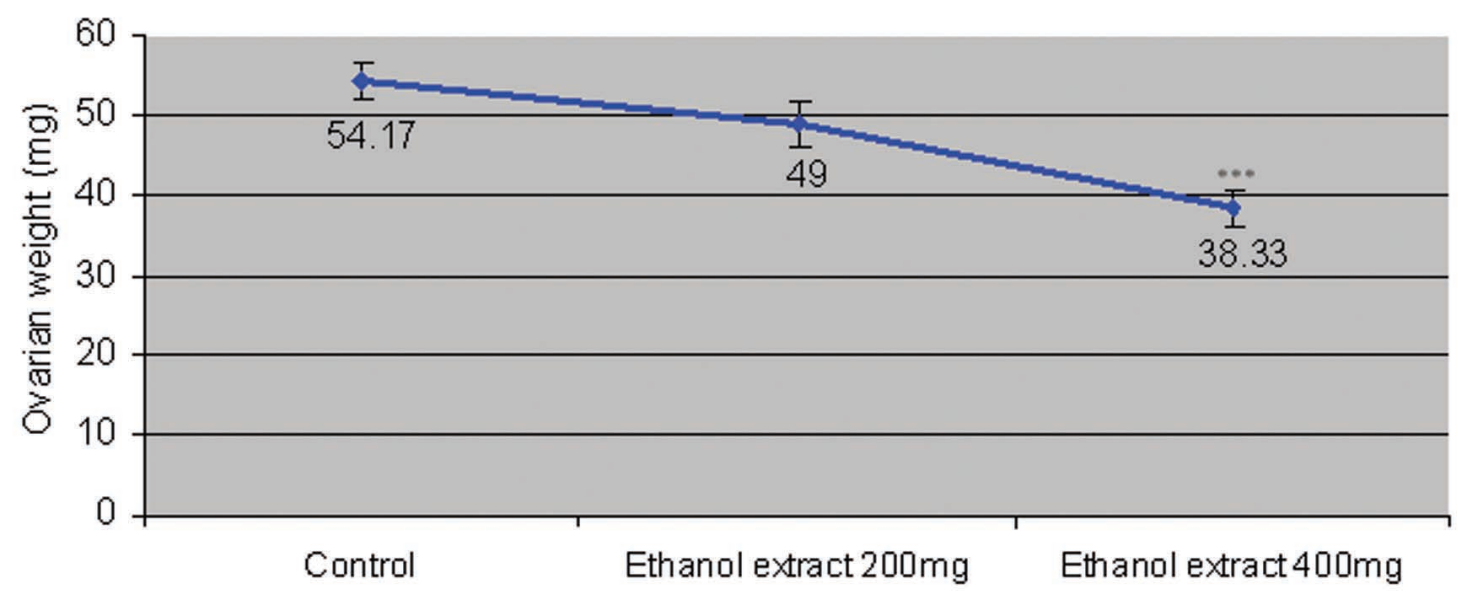

Fig. 4. Effect of ethanol extract of Trichosanthes cucumerina L. var. Cucumerina on ovarian weight. Data represent the mean \pm SEM. ( $n=6$ for each group). $* * * \mathrm{P}<0.001$ statistically significant difference from control.

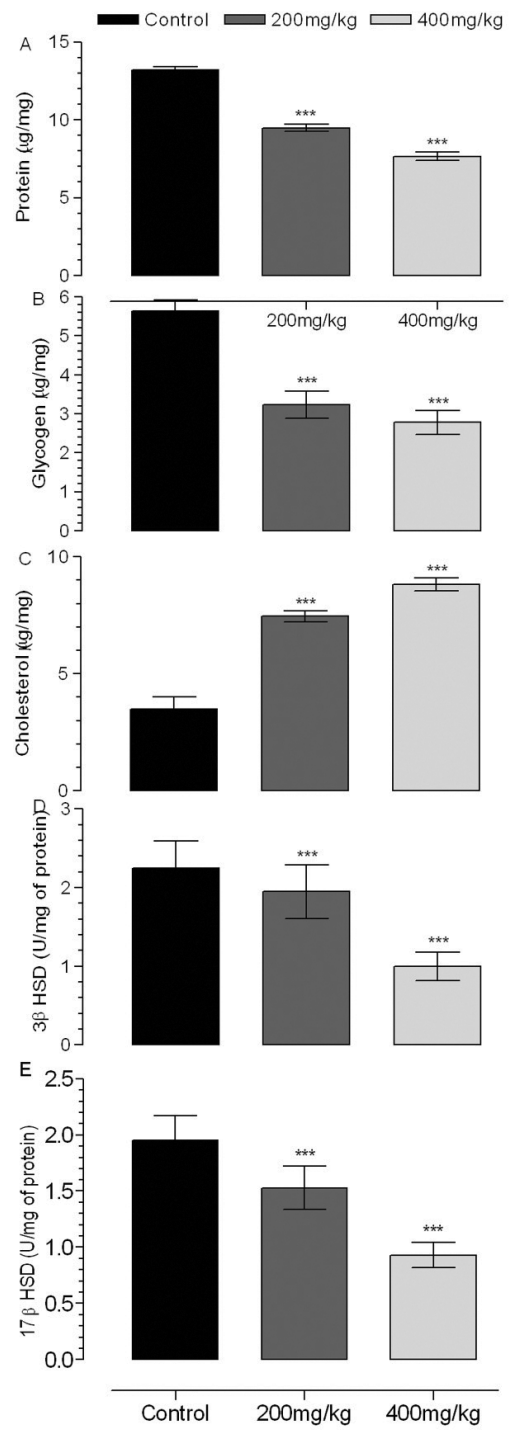

Fig. 5. Effect of ethanol extract of Trichosanthes cucumerina L. var. cucumerina on content of protein (A), glycogen (B) and cholesterol (C), and enzyme activities of 3b HSD (D) and 17b HSD (E) in rat ovary. Data represent the mean \pm SEM. $(n=6$ for each group). $* * * \mathrm{P}<0.001$ statistically significant difference from control.

(SAF) follicles. Significant $(\mathrm{P}<0.05)$ and highly significant $(\mathrm{P}<0.001)$ decrease of Class IV (MSAF) follicles were observed in low and high doses respectively. Class V (LSAF) follicles were decreased nonsignificantly and highly significantly $(\mathrm{P}<0.001)$ in both low and high doses respectively. Class VI (GF) follicles were decreased significantly $((\mathrm{P}<0.01)$ in low dose but completely absent in high dose. Number of corpora lutea were decreased significantly $(\mathrm{P}<0.01)$ and highly significantly $(\mathrm{P}<0.001)$ in both low and high doses respectively (Fig.6).

Regressing follicles: Highly significant reduction $(\mathrm{P}<0.001)$ of regressing follicles like Stage IA, Stage IB, Stage IIA and Stage IIB were observed in both low and high doses (Fig.7).

Hormonal changes. Serum FSH and LH levels were reduced highly significantly $(\mathrm{P}<0.001)$ in both low and high dose treated rats when compared to control (Fig.8).

Phytochemical analysis. Phytochemical analysis of the extract showed that it contained alkaloids, flavonoids, glycosides, lignin, phenols, saponins, sterols, tannins (Table I). 
KAGE, D. N.; MALASHETTY, V. B.; SEETHARAM, Y. N.; SURESH P. \& PATIL, S. B. Effect of ethanol extract of whole plant of Trichosanthes cucumerina var. Cucumerina L. on gonadotropins, ovarian follicular kinetics and estrous cycle for screening o antifertility activity in albin rats. Int. J. Morphol., 27(1):173-182, 2009.

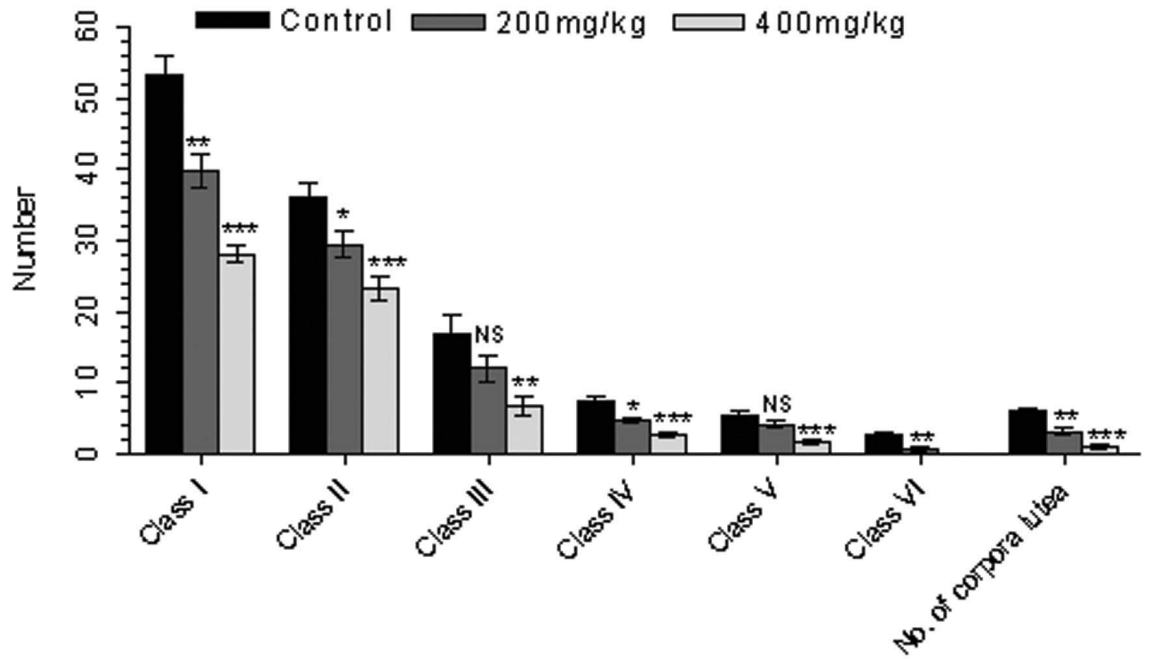

Fig. 6. Effect of ethanol extract of Trichosanthes cucumerina L. var. cucumerina on healthy follicles of rat ovary. Data represent the mean \pm SEM. $\left(n=6\right.$ for each group). $* \mathrm{P}<0.05$, ${ }^{*} * \mathrm{P}<0.01$, $* * * \mathrm{P}<0.001$ statistically significant significant difference from control.

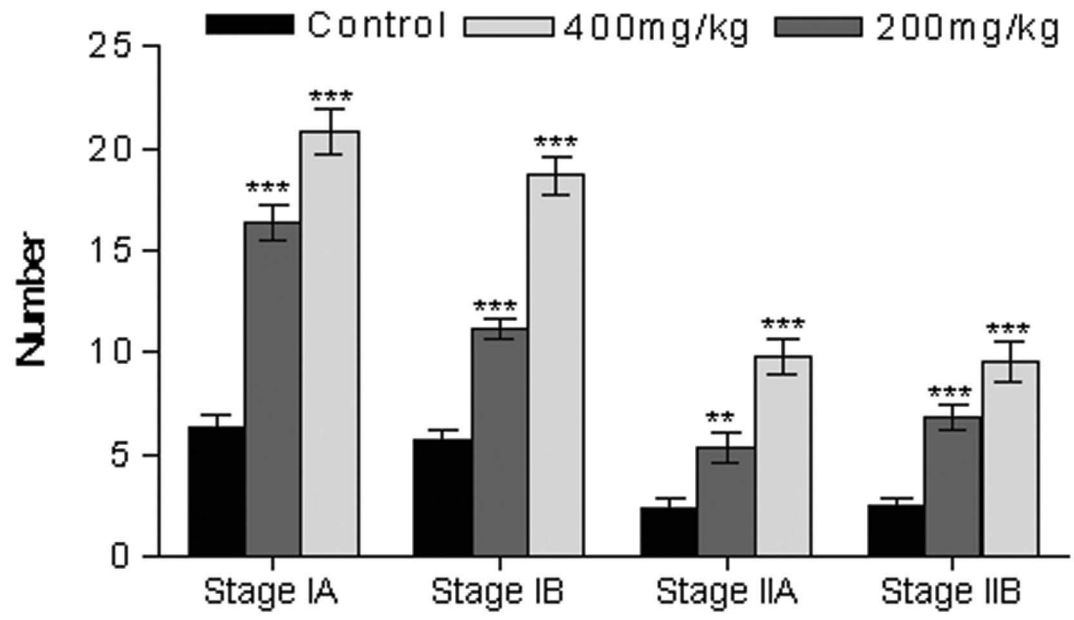

Fig. 7. Effect of ethanol effect of Trichosanthes cucumerina L. var. cucumerina on regressing follicles of rat ovary. Data represent the mean \pm SEM. ( $n=6$ for each group). ${ }^{* * P}<<0.01$, $* * * \mathrm{P}<0.001$ statistically significant difference from control.

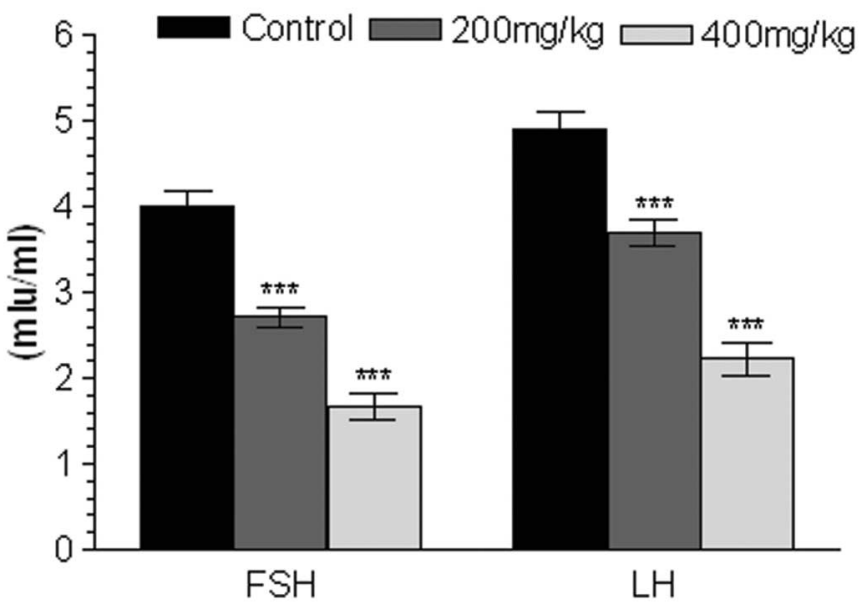

Fig. 8. Effect of ethanol effect of Trichosanthes cucumerina L. var. cucumerina on serum FSH and LH. Data represent the mean \pm SEM. $(n=6$ for each group). $* * * \mathrm{P}<0.001$ statistically significant difference from control. 
KAGE, D. N.; MALASHETTY, V. B.; SEETHARAM, Y. N.; SURESH P. \& PATIL, S. B. Effect of ethanol extract of whole plant of Trichosanthes cucumerina var. Cucumerina L. on gonadotropins, ovarian follicular kinetics and estrous cycle for screening o antifertility activity in albin rats. Int. J. Morphol., 27(I):173-182, 2009.

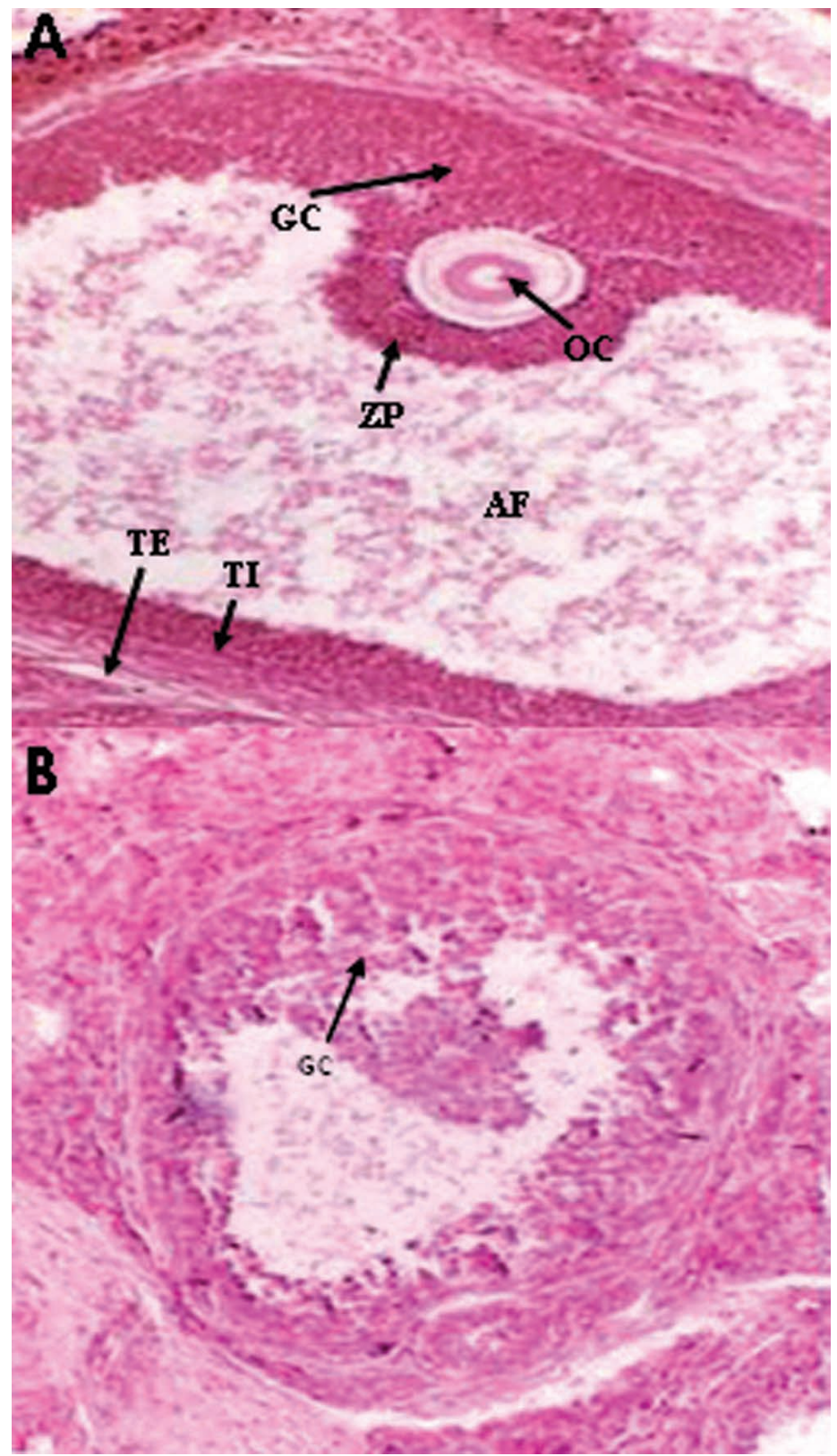

Fig. 9. The Graafian follicle of the control ovary showing normal development of the oocyte surrounded by zona pellucida with multiple layers of granulosa cells (A). In $400 \mathrm{mg} / \mathrm{kg}$ extract treated rats, granulosa cells are disorganized and the Graafian follicle shows the characteristics of follicular atresia (B). H \& E, 200X. TE-theca externa; TI-theca interna; AF-fluid filled antrum; ZP-zona pellucida; GC-granulose cells; OC-oocyte
Table I. Preliminary phytochemical tests for secondary metabolites of ethanolic extract of Trichosanthes cucumerina L. var. cucumerina. + , Positive; -, Negative.

\begin{tabular}{llc}
\hline $\begin{array}{l}\text { Secondary } \\
\text { metabolites }\end{array}$ & Name of the test & $\begin{array}{c}\text { Whole plant } \\
\text { (Ethanolic } \\
\text { extract) }\end{array}$ \\
\hline Alkaloid & Dragendorff's test & + \\
& Iodine test & + \\
& Wagner test & + \\
Flavonoids & NaOH test & + \\
& Pew's test & - \\
& Shinoda test & + \\
Glycosides & Kelnar-Kiliani test & + \\
& Conc. $\mathrm{H}_{2} \mathrm{SO} \mathrm{H}_{4}$ & + \\
Lignin & Labat test & + \\
Phenols & Ellagic test & + \\
& Phenols test & + \\
Saponins & Foam test & + \\
Sterols & Libermann-Bercard & + \\
& Salkowaski test & + \\
Tannins & Gelatin test & + \\
\hline
\end{tabular}

\section{DISCUSSION}

Follicle development is a complex and dynamic process requiring the coordinate interactions of multiple intragonadal and extragonadal factors (Richards, 2001; Richards et al., 2002). Pituitary hormones as well as growth factors and steroids derived from the gonads play key in regulating specific aspects of folliculogenesis (Wassarman \& Albertini, 1994). The basic functional unit of reproduction within the ovary is the follicle (Hsueh et al., 1984). Follicles start to grow at all times and as they develop, they produce large number of granulosa and thecal cells. The conversion of follicles to atretic state is functional rather than a degenerative process and is considered to be integral part of ovarian function (Hirshfield). Most of the follicles undergo

Table II. Effect of ethanol extract of Trichosanthes cucumerina L. var. cucumerina on organ weights (g/100g) of rats. Values are expressed as mean \pm SEM, $n=6$.

\begin{tabular}{llllllllll}
\hline Treatment & Heart & Liver & Kidney & Lung & Spleen & Adrenals & Esophagus & Stomach & Large \\
\hline Control & $0.94 \pm 0.06$ & $4.90 \pm 0.38$ & $0.82 \pm 0.03$ & $0.95 \pm 0.04$ & $0.53 \pm 0.02$ & $0.030 \pm 0.002$ & $0.058 \pm 0.00$ & $0.71 \pm 0.02$ & $0.99 \pm 0.04$ \\
$200 \mathrm{mg} / \mathrm{kg}$ & $1.00 \pm 0.06$ & $4.95 \pm 0.35$ & $0.83 \pm 0.02$ & $1.00 \pm 0.03$ & $0.55 \pm 0.01$ & $0.033 \pm 0.003$ & $0.058 \pm 0.001$ & $0.74 \pm 0.02$ & $1.00 \pm 0.02$ \\
$400 \mathrm{mg} / \mathrm{kg}$ & $0.95 \pm 0.01$ & $4.81 \pm 0.24$ & $0.82 \pm 0.02$ & $0.96 \pm 0.03$ & $0.57 \pm 0.02$ & $0.035 \pm 0.002$ & $0.056 \pm 0.001$ & $0.73 \pm 0.02$ & $0.98 \pm 0.02$ \\
\end{tabular}


atresia and very few mature to ovulate among the new crop of recruited follicles during every cycle. After the early stage of gonadotropin independence, the entire process of follicle growth becomes dependent on the continuous presence of gonadotropins (Hodgen, 1989; Scott \& Hodgen, 1990). Evans et al. (1997) have shown that the ovarian androgen and inhibin secretion by follicles may play an important part in the regulation of FSH secretion and follicular dynamics. The integral role in the control of ovarian function is played by the hypothalamo-pituitary unit. Functioning in a coordinated manner with appropriate signals provided by ovary via pituitary gland is responsible for the synthesis and storage of gonadotrophins-LH and FSH. These glycoprotein hormones in turn play a key role as regulators of folliculogenesis.

Treatment of intact rats with ethanol extract of Trichosanthes cucumerina L. var. cucumerina at high dose showed a significant decrease in the ovarian weight, this might be associated with inhibition of release of tropic pituitary gonadotropins due to the negative feedback mechanism of the drug which is estrogenic in nature. This effect is further reflected in the decline of circulating pituitary gonadotropins like FSH and LH when measured in both treatment groups compared with the control rats.

In this study, treatment of the ethanol extract of Trichosanthes cucumerina L. var. cucumerina at both doses for 30 days showed a significant increase in the duration of estrous cycle with prolonged estrus and metestrus phases and decrease in diestrus and proestrus phases. Similar results have been obtained with Cortalaria juncea (Vijaykumar \& Saraswati, 2007), Hibiscus rosa sinensis (Murthy et al., 1997), Achyranthes aspera (Shibeshi et al., 2006) and Momordica charantia (Sharanabasappa et al., 2002) in rats and mice. The difference in the duration of estrous cyclicity between the control and the treatment groups is attributed to the vaginal cornification, influenced by the more estrogen production by the extract which is estrogenic in nature (Data not shown).

Histological examination of follicles of various classes in ovaries of treatment groups showed that there was arrest in the development of follicles. This could be attributed to the decline in pituitary gonadotropins support, as FSH is the critical regulator of growth and development of follicles (Wassarman \& Albertini). Additionally follicles undergo atresia significantly in both treatment groups when compared to the control.

Atretic follicles are degenerating preovulatory follicles. The degeneration of preovulatory follicles takes place due to nonavailability of steroidal hormones (essential for their maturation and differentiation), non-availability of local estrogen produced by granulosa cells, or imbalance in endogenous steroid, protein and hormones. The presence of increased atretic follicles in the rats treated with ethanolic extract, compared with control rats, indicates that the extract promotes the degeneration of preovulatory follicles.

Protein is considered to be the building material and is involved in the alteration of almost every physiological function. In the present study the low protein content of the ovary indicates the retarded ovarian growth. It is well understood that FSH is essential for protein synthesis in gonads (Means, 1975). The blockade of pituitary FSH releases in extracts treated rats might have resulted in low protein content.

The presence of glycogen plays very important role in reproduction. It is involved in providing energy to various processes like ovulation, transportation and survival of eggs and implantation. All these changes are hormone dependent (Walaas, 1952). The decreased ovarian glycogen content in ethanol extract of Trichosanthes cucumerina L. var. cucumerina treated rats may be due to lowered steroidogenesis, which attributed to nonavailability of gonadotropins.

The decrease in pituitary gonadotropins both FSH and $\mathrm{LH}$ after treatment is reflected in the decline of ovarian function. FSH and LH are required for steroidogenesis and cholesterol is the principle starting key molecule required for steroid hormone biosynthesis within the ovary. The utilization of cholesterol is affected due to the deprivation of tropic support by the pituitary gonadotropins. The level of cholesterol significantly increased in the ovaries treated with ethanol extract of Trichosanthes cucumerina L. var. cucumerina at both doses, which clearly defines the role of gonadotropins in consuming cholesterol for steroid hormone biosynthesis within the ovary. Alternatively the effect of this drug upon cholesterol utilization enzymes like 3b HSD and 17b HSD to synthesize steroid hormones cannot be ignored. This effect is reflected in drastic decrease in the enzyme activities of ovaries after treatment with high dose of ethanol extract Trichosanthes cucumerina L. var. cucumerina. Our results suggest that ovarian steroidogenic function is impaired after treatment with ethanol extract along with decreased pituitary gonadotropins release when compared to control group.

The results showed that these plant extracts decreased $\mathrm{LH}$ and FSH release. The difference in the release of the two gonadotropins could be explained by the different secretion of the two gonadotropins in the oestrous cycle (Ayier \& Fink, 1974). Dalkin et al. (1990) showed that the different behaviours of LH and FSH could be explained by the fact that FSH gene expression is regulated by inhibin and partially by oestradiol and LHRH whereas, $\mathrm{LH}$ expression is regulated 
KAGE, D. N.; MALAShETTY, V. B.; SEETHARAM, Y. N.; SURESH P. \& PATIL, S. B. Effect of ethanol extract of whole plant of Trichosanthes cucumerina var. Cucumerina L. on gonadotropins, ovarian follicular kinetics and estrous cycle for screening o antifertility activity in albin rats. Int. J. Morphol., 27(I):173-182, 2009.

by LHRH and oestradiol. The marked decrease of LH and FSH could explain the ovulation and oestrous cycle blockade by the plant extract. Several authors demonstrated that the LH release surges at the proestrous stage are responsible for ovulation (Brown-Grant et al., 1970; Gallo, 1981; Hashimoto et al., 1987). All substances able to inhibit this release could provoke an ovulation disruption by decreasing the number of mature follicles or inducing an oestrous cycle disruption at a rest stage.

The molecular mechanisms by which this drug brings about decline in pituitary gonadotropins other than negative feed back mechanisms as they are estrogenic in nature is unclear. It could be possible that drug could control the synthesis and release of these gonadotropins at the level of transcription of gonadotropin subunits, act directly on the gonadotropin receptors in the ovary. Additional studies are still required to confirm the above.

In conclusion, the ethanol extract of whole plant of Trichosanthes cucumerina L. var. cucumerina reduced the serum levels of gonadotropins, might have affected folliculogenesis and steroidogenesis in ovary.

KAgE, D. N.; MALASheTtY, V. B.; SEEThaRAM, Y. N.; P. SURESH \& PATIL, S. B. Efectos del etanol extraído de la planta completa de Trichosanthes cucumerina var. Cucumerina L. sobre gonadotropinas, cinética folicular ovárica y ciclo para screening de actividad antifertilidad en ratas albinas. Int. J. Morphol., 27(1):173-182, 2009.

RESUMEN: El extracto de etanol de toda la planta de Trichosanthes cucumerina var. cucumerina (L.) se evaluó en cuanto a su actividad antiovulatoria en ratas adultas. El extracto de etanol en dosis de 200 y 400mg/kg de peso corporal (oral) afectó el ciclo normal estral, mostrando un aumentó significativo en las fases de estro y metaestro y la disminución de las fases de diestro y proestro. El extracto también redujo significativamente el número de folículos sanos (Clase I=Clase VI) y cuerpo lúteo y aumentó el número de folículos en regresión (etapa I, etapa IB, etapa II y etapa IIB). La proteína y el contenido de glucógeno en los ovarios se redujeron significativamente en las ratas tratadas. El nivel de colesterol aumentó significativamente, mientras que, actividad de las enzimas 3b-HSD y 17b-HSD se inhibió significativamente en el ovario de ratas tratadas. FSH sérico y los niveles de LH se redujeron significativamente en los grupos tratados y medidos por RIA. En la prueba de toxicidad aguda, no hubo mortalidad ni cambio en el comportamiento fisiológico o de cualquier otra actividad en los grupos tratados de ratas. En estudios de toxicidad crónica, no se registró mortalidad y no hubo diferencias significativas en el peso corporal o el peso de los órganos entre los controles y las ratas tratadas. Los análisis hematológicos no mostraron diferencias significativas en ninguno de los parámetros examinados (eritrocitos, recuento de glóbulos blancos y estimación de hemoglobina). Estas observaciones mostraron la actividad antiovulatoria del extracto de etanol de toda la planta de Trichosanthes cucumerina var. cucumerina en ratas albinas hembras.

PALABRAS CLAVE: Trichosanthes cucumerina var. cucumerina; Antifertilidad; Foliculogenesis; Ciclo estral; Gonadotrofinas; Actividad 3 b-HSD, 17 b-HSD; Esteroidogénesis ovárica.

\section{REFERENCES}

Aiyer, M. S. \& Fink, G. The role of sex steroid hormones in modulating the responsiveness of the anterior pituitary gland to luteinizing hormone releasing factor in the female rat. $J$. Endocrinol., 62:553-72, 1974.

Anonymous. The wealth of India. In: Raw materials: Publications and Information Directorate. New Delhi, CSIR, 1976.

Brown-Grant, K.; Exley, D. \& Naftolin, F. Peripheral plasma oestradiol and luteinizing hormone concentrations during the oestrous cycle of the rat. J. Endocrinol,. 48:295-6, 1970.

Carrol, N. V.; Langelly, R. W. \& Row, R. H. Glycogen determination in liver and muscle by use of anthrone reagent. J. Biol. Chem,. 20:583-93, 1956.

Chakravarthy, H. L. Fascicles of flora of India. (Fascicle 11) Botanical Survey of India, Howra. 1982.
Chopra, R. N.; Nayar, S. L. \& Chopra, I. C. Glossary of Indian Medicinal Plants. New Delhi, CSIR, 1969.

Choudhury, B. Vegetables. New Delhi, India, National Book Trust, 1967. pp.152-4.

Dalkin, A. C.; Haisenleder, D. J.; Otolando, G. A.; Suhr, A. \& Marshall, J. C. Gonadal regulation of gonadotropin subunit gene expression: Evidence for regulation of folliclestimulating hormone 13 messenger ribonucleic acid by non steroidal hormones in female rats. Endocrinology, 103:798806, 1990 .

Evans, A. C.; Komar, C. M.; Wandji, S. A. \& Fortune, J. E. Changes in androgen secretion and lutenizing hormone pulse amplitude are associated with the recruitment and growth of ovarian follicles during the luteal phase of the bovine estrous cycle. Biol. Reprod., 57:394-401, 1997. 
KAGE, D. N.; MALASHETTY, V. B.; SEETHARAM, Y. N.; SURESH P. \& PATIL, S. B. Effect of ethanol extract of whole plant of Trichosanthes cucumerina var. Cucumerina L. on gonadotropins, ovarian follicular kinetics and estrous cycle for screening o antifertility activity in albin rats. Int. J. Morphol., 27(1):173-182, 2009.

Figel, F. Spot test in organic analysis. London, Elsevier Publications Co., 1960. p.143.

Gallo, R. V. Pulsatile LH release during the ovulatory LH surge on proestrous in the rat. Biol. Reprod., 24:100-4, 1981.

Gamble, J. S. Flora of the Presidency of Madras. 1935. p.529.

Gibbs, R. D. Chemotaxonomy of flowering plants. Montreal, McGill Queen's University Press, 1974. pp.523-619.

Hashimoto, I.; Isomoto, N.; Eto, M.; Kawaminami, M.; Sunazuka, C. \& Ueki, N. Preovulatory secretion of progesterone, luteinizing hormone and prolactin in 4-day and 5-day cycling rats. Biol. Reprod,. 36:599-605, 1987.

Hirshfield, A. N. Development of follicles in the mammalian ovary. Int. Rev. Cytol,. 124: 43-101, 1991.

Hodgen, G. D. Neuroendocrinology of the normal menstrual cycle. J. Reprod. Med., 34(S1): 68-75, 1989.

Hsueh, A. J. W.; Adashi, E. Y.; Jones, P. B. C. \& Welsh, T. H. J. Hormonal regulation of the differentiation of cultured ovarian granulosa cells. Endocrine Rev., 5(1):76-127, 1984.

Kirtikar, K. R. \& Basu, B. D. Indian Medicinal Plants. New Delhi, India, Sri Satguru Publications, 2000. pp.1545-7.

Lowry, O. H.; Rosebrough, N. J.; Farr, A. L. \& Randall, R. J. Protein measurement with Folin phenol reagent. J. Biol. Chem., 193(1):265-75, 1951.

Means, A. R. Biochemical effects of follicle-stimulating hormone on the testis. Endocrinology, 5:203-17, 1975.

Murthy, D. R. K.; Reddy, C. M. \& Patil, S. B. Effect of benzene extract of $\mathrm{H}$. rosa inensis on the estrous cycle and ovarian activity in albino mice. Biol. Pharm. Bull., 20:756-8, 1997.

Peters, J. P. \& Vanslyke, D. D. Quantitative Clinical Chemistry. Baltimore, Williams \& Wilkins, 1946.

Pullaih, T. Encyclopaedia of world medicinal plants. New Delhi, Regency Publications, 2006. p.1977.

Richards, J. S. Perspective: the ovarian follicle-a perspective in 2001. Endocrinology, 142(6):2184-93, 2001.

Richards, J. S.; Russell, D. L.; Ochsner, S.; Hsieh, M.; Doyle, K. H.; Falender, A. F.; Lo, Y. K. \& Sharma, S. C. Novel signaling pathways control ovarian follicular development, ovulation, and luteinization. Recent. Prog. Horm. Res., 57:195-220, 2002.
Saldhana, C. J. Flora of Karnataka. New Delhi, Oxford \& IBH Publishing Company, 1984.

Sanjay, V. S. \& Joshi, B. N. Melatonin and exposure to constant light/darkness affects ovarian follicular kinetics and estrous cycle in Indian desert gerbil Meriones hurrianae (Jerdon). Gen. Comp. Endocrinol., 180(3):352-7, 1997.

Scott, R. T. Jr. \& Hodgen, G. D. The ovarian follicle: life cycle of a pelvic clock. Clin. Obstet. Gynecol., 33(3):551-62, 1990.

Seetharam, Y. N.; Kotresha, K. \& Uplaonkar, S. B. Flora of Gulbarga Disrict. Gulbarga, Gulbarga University, 2000. p.56.

Sharanabasappa, A.; Vijayakumar, B. \& Patil, S. B. Effect of Momordica charantia seed extracts on ovarian and uterine activities in albino rats. Pharmceutic. Biol., 40(7):501-7, 2002.

Shibeshi, W.; Makonnen, E.; Debella, A. \& Zerihum, L. Phytochemical, contraceptive efficacy and safety evaluations of the methanolic leaves extract of Achyranthes aspera L. in rats. Pharmacologyonline, 3:217-24, 2006.

Shivarajan, V. V. \& Indira, B. Ayurvedic drugs and their plant sources. New Delhi, India, Mohan Primlani for Oxford and IBH publishing Co. Pvt. Ltd., 1994.

Talalay, P. Hydroxysteroid dehydrogenases. Enzymology, 7: 5126, 1962.

Vijaykumar, B. M. \& Saraswati, B. P. Effect of chromatographic fractions of ethanolic extract of Crotalaria Juncea (L.) seeds on ovarian follicular kinetics and estrous cycle in albino rats. Iranian J. Pharmacol. Therap., 6(2):159-63, 2007.

Walaas, O. Effect of oestrogens on the glycogen content of the rat uterus. Acta Endocrinol., 10(2):175-92, 1952.

Wassarman, P. M. \& Albertini, D. F. The mammalian ovum. In: Knobil, E, Neill, J. D., editors. The physiology of reproduction, 2nd ed. New York. Plenum Publ. Co., 1994, V. 11. pp. 79-122.

Correspondence to:

Dr. Vijaykumar B Malashetty

Reproductive Biology Laboratory

Department of Zoology

Gulbarga University, INDIA

E-mail: vijaymalashetty@gmail.com

Received: 18-08-2008

Accepted: 18-11-2008 